\title{
ARTICLE \\ Civil Liability of a Company Director in the Vicinity of Insolvency: The Lithuanian Approach
}

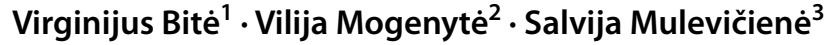

Accepted: 13 January 2022 / Published online: 7 February 2022

(c) T.M.C. Asser Press 2022

\begin{abstract}
Little has been achieved at the EU level and internationally to harmonise the various approaches taken by national laws regarding the nature and extent of directors' obligations in the vicinity of insolvency. The first steps towards harmonisation can be seen in the Restructuring Directive, which aims to provide initial guidance on the duties of directors where there is a likelihood of insolvency. Lithuania is one of the countries which has most recently implemented a comprehensive insolvency reform, trying to better conform to the modern realities of business and promote the corporate rescue paradigm through the national legal regime. The new Law on Insolvency of Legal Persons introduced a range of changes that directly and indirectly impact the director's civil liability approach. The aim of this paper is to provide comprehensive insights from a comparative perspective on the Lithuanian approach to the regime of a director's civil liability in the vicinity of insolvency through an analysis of the conditions and sources of such liability in the context of the new legal regime of insolvency. The paper discusses the general features and doctrine of the legal regime regarding a director's civil liability in Lithuania. Secondly, it sets out the types of insolvency-related duties of directors, analyses the current state of harmonisation at the EU level in that regard, and then discusses the Lithuanian approach. Finally, it determines the main factors influencing the future of the legal regime of a director's liability, including the reactions of the legislators to the COVID-19 outbreak.
\end{abstract}

Keywords Company director · Directors' duties · Directors' civil liability · Imminent insolvency · Vicinity of insolvency · Insolvency law reform

Virginijus Bitè

virginijus.bite@mruni.eu

Extended author information available on the last page of the article 


\section{Introduction}

Currently, insolvency law is still primarily regulated at the national level in the European Union (EU), but over the last decade insolvency law has moved from the margins of European legislative activity to the centre. The European Commission now identifies well-functioning insolvency law as an essential part of a good business environment and considers a higher degree of European harmonisation to be important for a well-functioning single market. ${ }^{1}$

The first important EU legal act in the area of insolvency-the Regulation on insolvency proceedings of $2000^{2}$ and its Recast of $2015^{3}$ (hereinafter EU Insolvency Regulation)—covered only cross-border issues and did not harmonise Member States' substantive insolvency laws. Later, the focus was shifted to the enhancement of the 'rescue culture' in the EU. The recent (2019) EU Directive 2019/1023 on preventive restructuring frameworks ${ }^{4}$ (hereinafter the Restructuring Directive) already grants (at least at the EU level) a so-called 'second chance' to businesses in EU markets. Another problematic field, which is still extensively debated in the doctrine and at the political level both in the EU and internationally, is the question of the liability of companies' directors in the period approaching insolvency. ${ }^{5}$ According to the Proposal for the Restructuring Directive ${ }^{6}$ (hereinafter the Proposal), the rules on a company director's duty of care when nearing insolvency play an important role in developing a culture of business rescue instead of liquidation as they encourage early restructuring, preventing misconduct and avoidable losses for creditors.

The immediate period before insolvency, referred to as the 'twilight zone', ${ }^{7}$ is a dangerous period for the creditors of a company. Doctrinal commentary identifies that a combination of the default law rules of a company (separate corporate personality, limited liability of shareholders, and board management of a company's affairs) gives rise to a risk of opportunistic conduct by directors, to the detriment of creditors, when a company is insolvent or nearing insolvency. ${ }^{8}$ Shareholders can incite directors to embark upon risky projects (at the expense of creditors) to try

\footnotetext{
1 Weijs (2018), p 404.

2 Regulation (EC) No. 1346/2000, OJ L 160, 30.6.2000, p 1.

3 Regulation (EU) No. 2015/848, OJ L 141, 5.6.2015, p 19.

4 Directive 2019/1023 (Directive on restructuring and insolvency), OJ L 172/18, 26.06.2019.

5 See, e.g., UNCITRAL (2013).

6 Proposal for a Directive of the European Parliament and of the Council on preventive restructuring frameworks, second chance and measures to increase the efficiency of restructuring, insolvency and discharge procedures and amending Directive 2012/30/EU, COM(2016) 723 final, 2016/0359 (COD), p 6, https://ec.europa.eu/information_society/newsroom/image/document/2016-48/proposal_40046.pdf (accessed 3 October 2020).

7 In academic literature the terms 'vicinity of insolvency', 'zone of insolvency' and 'twilight of insolvency' are used interchangeably to generally describe a company's pre-insolvency stages - either imminent insolvency or the status of less significant financial difficulties. See, e.g., Scarlino (2018). In this paper the term 'vicinity of insolvency' is used exclusively to define the status of the company's financial distress when a director might still have reasonable hope for the company's financial recovery in the future.

8 Taylor (2018), p 173; Williams (2015), p 56; Keay (2005), pp 433-434.
} 
to preserve some value for themselves. ${ }^{9}$ The rules on a director's liability serve to counterbalance this gamble. ${ }^{10}$ This presupposes that developing a reasonably strict civil liability regime for directors could deter commercially inappropriate conduct. Also, in cases of loss, creditors could redress damages from the responsible officer. However, overly harsh unrestricted applicability of the director's civil liability regime could be dangerous to the state economy since it would most definitely discourage directors from engaging in potentially beneficial, although risky, business ventures, which might lead to economic stagnation, at least to some extent. Hence, legal systems are prevailed upon in the ongoing quest for a higher level of balance in regulations that impose civil liability on directors in the vicinity of insolvency. ${ }^{11}$

Despite the importance of this topic and the scientific debates around it, little has been achieved both at the EU level and internationally to harmonise the various approaches of national laws regarding the nature and extent of the obligations that directors might have in the twilight zone, where a business is experiencing financial distress but is not yet insolvent (or at least where this is unclear). Only the first steps towards this harmonisation can be seen in the Restructuring Directive, which, despite the considerable differences between Member States' laws regarding the liability of directors, aims to provide initial guidance on the duties of directors where there is a likelihood of insolvency (see Article 19).

The general duties of a director in Europe are a matter for the law of the place of incorporation of the company. However, this question can become difficult if the company acts in various countries, because then the applicable law will be determined based on the concept of the centre of main interests (COMI), which is a moving factor (the company can decide at any time to move its central administration from one country to another ${ }^{12}$ ). Currently, Article 6 of the EU Insolvency Regulation provides that the lex concursus ${ }^{13}$ applies to actions which derive from insolvency proceedings and are closely linked to them, such as avoidance actions against defendants in other Member States ${ }^{14}$ and those who are resident in non-EU Member States. ${ }^{15}$ The European Court of Justice (hereinafter ECJ) also previously stated that actions brought by the liquidator in the insolvency proceedings against the managing director of a company derive directly from the insolvency proceedings, and are closely connected to them. ${ }^{16}$ Such an approach is also prevalent in the doctrine. ${ }^{17}$

\footnotetext{
9 Lennarts et al. (2017), p 40.

10 Armour et al. (2017), p 109.

11 Mevorach and Walters (2020), p 7.

12 Brinkmann (2019), p 52.

13 Art. 4(1) provides that 'the law applicable to insolvency proceedings... shall be that of the Member State within the territory of which such proceedings are opened' (the lex concursus). Recital 66 provides that the Regulation should set out 'uniform rules on conflict of laws' to replace national conflict of law rules.

14 ECJ, C-339/07, Seagon v. Deko Marty Belgium, ECLI:EU:C:2009:83

15 ECJ, C-328/12, Schmid v. Hertel, ECLI:EU:C:2014:6

16 ECJ, C-295/13, H v. H.K, ECLI:EU:C:2014:2410.

17 Madaus (2019), p 80.
} 
So, if the COMI either changes or is determined not to be in an incorporation country, difficult questions arise as to whether the directors can be held liable for the breach of insolvency-related duties based on the law of the country which is not the incorporation country. Due to the lack of harmonisation in this area, different national approaches currently provide different outcomes. At the EU level, the question of different national approaches to the director's liability in the vicinity of insolvency gained special relevance after the decision of the ECJ in the Kornhaas case. ${ }^{18}$ In this decision, the ECJ pointed out that the law of the main insolvency proceedings also determines the applicable law for the director's liability (both the extent and the enforcement of the liability), notwithstanding the fact that the debtor (the insolvent company) and its director are located in another Member State. ${ }^{19}$

The takeaway from the Kornhaas case is that the director of a company incorporated in one Member State but with central administration/main operations in another Member State should take into account the potential consequences of any COMI migration for the law applicable to their duties in the vicinity of insolvency, and be sure to be informed on the main features of any relevant law related to directors' duties.

Thus, the aim of this paper is to provide comprehensive insights from a comparative perspective on the Lithuanian approach to a director's civil liability regime in the vicinity of insolvency through an analysis of the defined conditions and sources of such liability in the context of a new legal regime of insolvency. This will allow for an understanding of what practical implications await the legal entities, their directors, their creditors and their shareholders if the lex fori applicable to the question of the director's liability in the vicinity of insolvency happens to be Lithuanian law, and an understanding of how European trends are reflected in the national law of Lithuania. In addition, Lithuania is one of the countries which has most recently implemented a comprehensive insolvency reform, promoting a corporate rescue legal environment by considering the best practice available (and also aiming to improve the country's position in the World Bank Doing Business rating ${ }^{20}$ ). The new Law on Insolvency of Legal Entities ${ }^{21}$ (hereinafter LILE) only entered into force on 1 January 2020 (significant changes of the LILE related to directors' liability in the vicinity of insolvency came into force on 15 July 2021). It introduced a range of changes that directly and indirectly impact a director's civil liability. Therefore, it is a good example to illustrate how current European and international trends in insolvency are being understood and implemented in the framework of domestic insolvency.

\footnotetext{
18 ECJ, C-594/14, Kornhaas v. Dithmar, ECLI:EU:C:2015:806.

19 In a concrete case (Kornhaas v. Dithmar), this rule meant that the English director of K Montage found himself personally liable under German law, because the court decided that the COMI of the company incorporated in England was in Germany and insolvency proceedings had been commenced there.

20 World Bank, Doing Business, Measuring Business Regulations. Resolving Insolvency, 2019. http:// www.doingbusiness.org/data/exploretopics/resolving-insolvency (accessed 3 October 2020).

21 Law on Insolvency of Legal Entities of the Republic of Lithuania No. XIII-2221 of 2019 (Register of Legal Acts, 2019, No. 10324).
} 
First, the general features and doctrine of the legal regime regarding a director's civil liability in Lithuania will be discussed. Second, we will set out the types of insolvency-related duties of directors in the EU Member States, analyse the current status of harmonisation in that regard at the EU level, and then discuss the Lithuanian approach from this comparative perspective. Finally, we will determine the main factors influencing the future of the legal regime governing directors' liability, including the reactions of legislators to the COVID-19 outbreak.

\section{The Anatomy of the Legal Regime Regarding a Director's Civil Liability in Lithuania}

In this Section, some preliminary issues will be addressed to reveal several basic concepts needed for a deeper understanding of the Lithuanian approach to directors' liability in the vicinity of insolvency. These will include: general insights on companies' board structures; statutory provisions and the legal doctrine on directors' duties; and transaction avoidance that may serve as a foundation for liability claims against directors.

\subsection{The Lithuanian Approach to Companies' Managing Bodies}

The Law on Stock Companies of the Republic of Lithuania ${ }^{22}$ (hereinafter LSC) stipulates that a company must have a single-person managing body-a company director-and only a natural person is allowed to hold this office. ${ }^{23}$ Respectively, the director and the company are bound by a civil legal relationship. The principle that the director represents the company ex officio is entrenched in Lithuanian legislature. ${ }^{24}$ Accordingly, the director acts on behalf of the company, without separate authorisation. A director continuously acting ex officio is a key person in the company, through which legal entities acquire all rights and assume all duties. ${ }^{25} \mathrm{~A}$ company might also have a collegial supervisory body-a supervisory council, a collegial management body, or a board of directors-but only in a public limited company is it the case that at least one collegial body must be formed. ${ }^{26}$ Thus, in Lithuania, there is no statutory obligation to establish a collegial management body such as a board of directors. Therefore, the current structure of company bodies in Lithuania does not actually correspond to either one-tier or two-tier corporate governance systems, since the head of a company is distinguished as a separate management body. In this way, the board of directors, being a management body, is deprived of its exclusive authority to represent the company before third parties, and

\footnotetext{
${ }^{22}$ Law on Stock Companies of the Republic of Lithuania No. VIII-1835 of 2000 (State News, 2000, No. 64-1914) (with further amendments and supplements).

23 Arts. 19(1), 37(1) and 37(2) LSC.

24 Art. 2.81(1) CC; Art. 37(10) LSC.

25 Mikelènas et al. (2002), comment on Art. 2.87(1).

26 Art. 19(2) LSC.
} 
in most cases is only a higher-level management body but not the only executive body of a company. ${ }^{27}$

The core civil director's accountability provision is that a managing body, in this case a company director as a natural person, who fails to perform or improperly performs their specified duties, must redress all damages incurred on a legal person except as otherwise provided by law, incorporation documents, or an agreement. ${ }^{28}$ Thus, non-fulfilment or violation by a director of the statutory duties as a singleperson governing body — such as failure to apply for insolvency in a timely manner, preserve the company's assets, or investigate significant information-is subject to civil liability.

\subsection{The Basics for Directors' Civil Liability in Lithuania}

With reference to the Lithuanian Civil Code $^{29}$ (hereinafter CC), Article 6.263, the grounds for a director's civil liability is tort. ${ }^{30}$ As repeatedly explicated in the practice of the Supreme Court of Lithuania (hereinafter SCL), in order to apply civil liability to a director all of the necessary pre-conditions must be identified: (1) unlawful acts; (2) damage caused; (3) causality between unlawful acts and damage caused; and (4) fault. ${ }^{31}$ After an assessment of the director's unlawful actions that caused specific damage, the fault of the director is legally presumed. ${ }^{32}$ The burden of refuting the presumption of fault is passed to directors themselves. ${ }^{33}$

Previously, under Lithuanian case $\operatorname{law}^{34}$ as well as under Lithuanian legal doctrine, ${ }^{35}$ the duty of care was considered a fiduciary duty. Such an approach is typical of Delaware law, but UK, Australian and civil law jurisdictions have adopted a narrower view, where the duty of care is recognised to be non-fiduciary in nature. ${ }^{36}$ In its later case law, ${ }^{37}$ the SCL has leaned towards the second approach. It is also true that the SCL does not directly use the term 'duty of care', but instead indicates the adoption of detrimental business decisions as one of the grounds for a director's civil liability, in addition to breach of imperative (specific) and fiduciary duties.

The extent and specifics of the burden of proof for the claimant in cases regarding a civil director's liability vary according to the abovementioned origin of the tort. The Lithuanian legal approach suggests a range of managerial responsibilities

\footnotetext{
27 Bitė and Jakuntavičiūtė (2014 b), p 49.

28 Art. 2.87(7) CC.

29 Civil Code of the Republic of Lithuania (State News, 2000, No. 74-2262) (with further amendments and supplements).

30 SCL, Case 3K-3-214/2011 (29.04.2011).

31 Art. 6.246-6.249 CC.

32 Art. 6.248(1) CC.

33 E.g., SCL, Case 3K-7-444/2009 (20.11.2009); Case 3K-3-130/2011 (25.03.2011).

34 E.g., SCL, Case 3K-3-334/2010 (20.07.2010); Case 3K-7-444/2009 (20.11.2009); Case 3K-3528/2009 (30.11.2009).

35 E.g., Abramavičius and Mikelènas (1999), p 286; Greičius (2007), p 130.

36 Hill (2020), p 10; Flannigan (2006), p 231.

37 E.g., SCL, Case 3K-7-177-701/2017 (16.10.2017).
} 
regarded as imperative duties of the director, inter alia, in cases of contentious financial difficulties and pending insolvency: initiating legal insolvency proceedings in a timely manner, submitting a company's documents and assets to the insolvency practitioner after bankruptcy proceedings have been initiated against the company, ${ }^{38}$ etc.

Lithuanian legal regulation is formed based on the concept of the fiduciary duty of loyalty, indicating a director's straightforward obligation to be loyal to the legal person and to maintain confidentiality, ${ }^{39}$ as well as to act ex officio solely for the benefit of the company and its shareholders. ${ }^{40}$ In cases where the assertion has been made that a director is using company assets not in accordance with their fiduciary duties, an unlawful act by the director can be presumed. ${ }^{41}$

In determining whether a director has breached their duty of care, the Lithuanian case law applies the standard of 'reasonable director', meaning that a director must use the amount of care that an ordinarily careful, qualified and prudent executive (manager) or entrepreneur would use in similar circumstances. ${ }^{42}$ The subjective professional attributes of a particular individual can only raise the bar of this standard. ${ }^{43}$ This means that an objective-subjective standard is applicable. An analysis of directors' liability in the context of the stages of pre-insolvency and insolvency suggests that one of the most important obligations of the director, ascendant from the duty of care, is the imperative to protect and properly account for the assets of the company, and to keep data on the company's financial operations for the statutory period. ${ }^{44}$

It is worth mentioning the development of Lithuanian case law on the application of the business judgement rule (hereinafter BJR). Before 2014, the Lithuanian legal system did not recognise the judicial abstention doctrine, which emphasises a court's right not to consider ex-post criticism of directors' decisions. ${ }^{45}$ After 2014, in pursuance of balancing the positive aspects of business risk and reducing a director's liability for unfortunate business decisions, the SCL introduced the BJR expressis verbis in cases dealing with a director's civil liability. Traditionally, the BJR standard is built on the recognition that business ventures come with a degree of risk, and that even prudent and well-informed directors can make decisions that can ultimately cause great harm to a company. ${ }^{46}$ In a prominent ruling of the SCL that perpetuated the BJR as a standard for directors' liability, it was explicated that a director's civil liability arises not from business failures but from business decisions made in negligence of fiduciary duties, such as misuse of power or gross negligence. ${ }^{47}$ It is

\footnotetext{
38 Arts. 6 and 57(1, 2) LILE.

39 Art. 2.87(2) CC.

40 Art. 19(8) LSC; SCL, Case 3K-3-334/2010 (20.07.2016).

41 SCL, Case 3K-3-64-248/2016 (08.01.2016).

42 E.g., SCL, Case 3K-7-266/2006 (25.05.2006); Case 3K-3-130/2011 (25.03.2011); Case 3K-7124/2014 (09.01.2014); Case 3K-7-177-701/2017 (16.10.2017).

43 E.g., SCL, Case 3K-7-124/2014 (09.01.2014); Case 3K-3-130/2011 (25.03.2011).

44 SCL, Case 3K-3-429-313/2015 (03.07.2015).

45 Bitė and Gumuliauskienė (2016), p 574.

46 Barton et al. (1998), pp 12-13.

47 SCL, Case 3K-7-124/2014 (09.01.2014).
} 
however true that this rule does not eliminate previous Lithuanian case law requiring analysis both of the purport of business decisions and of the related decision-making process. ${ }^{48}$

While some jurisdictions (Delaware, Australia, etc.) have implemented the BJR as a presumption in favour of corporate directors, with the burden of proof lying on the plaintiff, other jurisdictions (see, e.g., Article 93 of the German Stock Corporation Act) have implemented the rule as a 'safe harbour', imposing the burden of proof on the directors. ${ }^{49}$ The SCL calls the rule a presumption. ${ }^{50}$ After introducing it through Lithuanian cassation practice, it became a prevailing legal tool in defence strategies during litigation, while courts appeared to be discernibly more reluctant to scrutinise the merits of business decisions.

The main agent entitled to sue the director for damages once the company enters formal insolvency proceedings is the appointed insolvency administrator. Insolvency administrators have to scrutinise all contracts concluded by the legal person at least 3 years before the beginning of the insolvency proceedings, and litigate upon relevant findings. ${ }^{51}$ They audit the director's execution of imperative and fiduciary duties, inspect business decisions made, and undoubtedly focus on the period when the company entered financial distress. If the insolvency administrator fails to execute this obligation, then the creditors themselves might also sue the director for compensation of damages, but only through an indirect claim. ${ }^{52}$ An analogous right to an indirect claim is also granted to the shareholders of the company. ${ }^{53}$ All amounts received shall be used pro rata to satisfy the claims of all creditors, respecting the order and terms for satisfaction as specified in the respective legal norms. ${ }^{54}$ Previous case law has stressed that the opposing interpretation-authorising individual creditors to sue the directors on their own behalf-would contravene the principle of creditors' equality, and the purpose of insolvency law itself, which is to prevent an internecine race between creditors. ${ }^{55}$

However, more recent Lithuanian case law has recognised the creditor's right to file a direct lawsuit against a director, but only in two exceptional cases: when the director's unlawful acts have caused direct damage to a particular creditor; or when the bankruptcy of a company is found to be fraudulent, and the director is found guilty of this fraudulent bankruptcy. ${ }^{56}$ Such a right of the creditor is not limited by the stage of bankruptcy, and can be exercised even after completion of formal

\footnotetext{
48 See also Bitė and Gumuliauskienė (2016).

49 Gurrea-Martínez (2018), p 6.

${ }^{50}$ Indeed, some Lithuanian authors argue that the BJR does not correspond to the criteria of the presumption. See Jarusevičius (2019), pp 197-198.

51 Art. 64(1) LILE.

52 Art. 6.68 CC; SCL, Case 3K-3-318/2014 (13.06.2014).

53 SCL, Case 3K-3-514/2009 (17.11.2009).

54 Arts. 94 and 95 LILE.

55 SCL, Case 3K-3-130/2011 (25.03.2011).

56 SCL, Case 3K-3-389/2014 (12.09.2014); Case 3K-3-211-469/2017 (04.05.2017); Case e3K-3-540469/2018 (31.12.2018).
} 
liquidation procedures of the company. ${ }^{57}$ The director's liability is applicable only in cases where a company itself is not capable of satisfying these claims. ${ }^{58}$ However, since the percentage of satisfaction of creditors' financial claims in Lithuanian bankruptcy proceedings is very low $(14.5 \%$, while the satisfaction percentage of the third creditor in line's claims is only $3.3 \%$, based on the latest available data from 2019), ${ }^{59}$ in the cases discussed this de facto means full-scale financial liability of the natural person-the company's former director.

\section{Directors' Duties and Liability in the Vicinity of Insolvency}

\subsection{Shift in Directors' Duties}

Once the company enters the zone of insolvency, there is a fundamental change in the balance of interests, thus a grand shift occurs regarding the beneficiary of the director's duties. ${ }^{60}$ Scholars mostly agree that directors of solvent companies manage the company on behalf of common shareholders and are under no obligation to consider the interests of the firm's creditors. Whereas a duty of care is not expected to change as to its content (although certain obligations are added/modified), ${ }^{61}$ the financial weakening of a company warrants a shift in the director's loyalty from the shareholders to the contractual creditors. ${ }^{62}$ Such a creditor-friendly approach prevails in civil law jurisdictions. In comparison, United States legal regulation is regarded as a debtor-friendly model, granting directors more leeway in deciding when to file for insolvency proceedings and generally making them more accountable to the firm. While creditors' rights are respected in financially troubled companies, there is no such distinct shift regarding the beneficiary of a director's fiduciary duties. ${ }^{63}$

The so-called 'grand shift' is prominent in the Lithuanian legal system. The SCL explicated that the content of the duty to act in the company's best interests depends on the financial situation of the company. As the company becomes financially weaker, the interests of its lenders increase, whereas when the financial situation of the company becomes extremely difficult or even critical, meaning that the company

\footnotetext{
57 SCL, Case 3K-3-389/2014 (12.09.2014); Case 3K-3-234/2013 (19.04.2013).

58 SCL, Case 3K-3-290/2013 (17.05.2013); Case 3K-3-295/2008 (03.06.2008).

59 Imonių bankroto ir restruktūrizavimo bei fizinių asmenų bankroto procesų 2019 m. sausio-birželio mèn. Apžvalga [Review of companies' bankruptcy and restructuring and natural persons' bankruptcy processes in 2019 January-June], 25.09.2019, No. (6.13)D4-1315. http://www.avnt.lt/assets/Veiklos-sritys/Nemokumas/Nemokumo-duomenys-ir-analize/2019-I-pusmSTATISTIKAI-APZVALGA2019-09-30. pdf. accessed 3 October 2020.

60 The theoretical background reasoning for such a shift towards extending the director's duties to creditors in troubled companies is found in the so-called at-risk doctrine and the trust fund doctrine. See also Kandestin (2007), pp 1237-1238; Hudson (2014), pp 61-62.

61 Havel (2018), p 107.

${ }^{62}$ E.g., Waxman (2014), p 1193; Armour et al. (2017), p 129; Gevurtz (2000), pp 304-313.

63 Hudson (2014), pp 75-76, 86.
} 
has reached its insolvency threshold, creditors' interests start to prevail. ${ }^{64}$ The latter suggests a gradual rather than an abrupt shift of the beneficiary of the director's duties from the company's shareholders to its creditors, indicating a direct correlation with the company's financial status.

\subsection{Doctrines on the Grounds for Liability of Directors in the Vicinity of Insolvency}

From a historical perspective, two main doctrines regarding the grounds for liability of directors in Europe can be distinguished.

The 'duty to file and the liability for delaying insolvency proceedings' doctrine. One main strategy used by the EU Member States to ensure creditors' interests are properly considered in the vicinity of insolvency is the duty for a director to file for insolvency in a timely manner. This duty on the part of the board of directors exists in the majority of the Member States (e.g., Austria, Belgium, France, Germany, Greece, Italy, Latvia, Poland and Spain). ${ }^{65}$ As the title suggests, the doctrine advocates the timely initiation of insolvency proceedings and supports the imposition of a director's liability for failure to act in respect of the company's creditors. The promoted duty in this sense is very strict and obliges directors to monitor a company's business activities and financial situation. It also encourages directors to enforce available measures when any financial difficulties are observed. ${ }^{66}$ Most EU Member States oblige directors to file for insolvency proceedings within a certain time period following the advent of particular circumstances. ${ }^{67}$ The circumstances that trigger the need for directors to file are described in various ways, but effectively involve insolvency occurring. The period that is prescribed varies between Member States, although the most common period is 30 days/1 month. Some Member States, besides setting an upper time limit for filing, also mandate that directors are to file without delay. If they do not do so, they may incur criminal penalties. ${ }^{68}$ Thus, in the context of a company's pre-insolvency stage, a director's timely action to minimise the effect of financial distress experienced by the enterprise along with its creditors (often meaning the initiation of formal insolvency proceedings) is regarded as the paramount duty a director owes to the company's creditors.

The 'liability for wrongful trading' doctrine. Instead of adopting the duty to file for insolvency, some Member States (England and Wales, Hungary, The Netherlands and Sweden-where it may also lead to criminal prosecution) provide for a duty to cease trading when creditors' interests are at risk, the so-called 'wrongful trading rule'. The term 'wrongful trading' is often employed in common law jurisdictions and is generally defined as a course of action or omission by a director that fails to

\footnotetext{
64 SCL, Case 3K-3-19/2012 (01.02.2012).

65 European Law Institute (2017), p 166.

66 Bitè and Jakuntavičiūtė (2014a), pp 117-118.

67 European Law Institute (2017), p 166.

68 McCormack et al. (2016), pp 51-52.
} 
minimise financial loss to creditors once a company is near insolvency. ${ }^{69}$ This means that a company 'trades wrongfully' if it incurs debts or other liabilities when insolvent (or becomes insolvent as a result of incurring such debts or other liabilities), without reasonable prospect of meeting them in full in the future. Among EU Member States where there is no formal requirement to file for insolvency within a specific time, most have some form of provision or case law dictating that while companies may continue to do business when they are near to, or actually in, insolvency (either on a cash-flow or balance-sheet basis), directors must modify their actions so as to halt a company's slide into insolvent liquidation, in order to protect creditors. This kind of provision can apply in the vicinity of insolvency where directors can foresee the inevitable insolvent liquidation of their company occurring unless steps are taken to ameliorate the position of the company's finances. For example, such a concept of wrongful trading is found in Hungary, where there is no duty to file for insolvency proceedings on the advent of insolvency if there exists what is referred to as 'threatening insolvency'. A director can, however, be held liable for not taking appropriate action when they knew or should have reasonably foreseen that the company would not be able to pay its debts as they became due. ${ }^{70}$

A third approach - the 'liability for deepening insolvency' doctrine-could be mentioned. However, it is a variation on the liability for wrongful trading doctrine and was mostly developed by the US courts. Continued corporate existence is often seen as a benefit because it fosters economic growth, maintains jobs, provides incentives for risky but possibly rewarding business undertakings, and generally benefits the community of interests that sustain a company. The theory of deepening insolvency, however, carves an exception to this general rule and suggests that where a company's life is artificially prolonged, such existence cannot be deemed beneficial either to the company or to its creditors. ${ }^{71}$ On the contrary, the wrongful prolongation of a company's existence beyond insolvency results in damage to creditors, usually caused by increased debt and the dissipation of assets. The theory has received criticism in doctrine due to its lack of a clear legal background ${ }^{72}$ and is not widely accepted in Europe as autonomous grounds for liability. It is based on the simple argument that a corporation is not a biological entity, for which it can be assumed that any act that extends its existence is beneficial to it. ${ }^{73}$ Thus, the continuation of the activities of a company that is obviously dying can be equated to a director's wrongful trading and the resultant damage to creditors.

There are also countries which use a hybrid approach. In Germany, for example, there is a statutory duty to file for insolvency under certain circumstances, but the

\footnotetext{
69 Davies et al. (1997), p 153.

70 McCormack et al. (2016), p 53.

71 Millner et al. (2007), p 26; see also the case of US District Court, S.D. New York Bloor v. Dansker (In re Investors Funding Corp. of N.Y. Security Litigation), 523 F. Supp. 533 (S.D.N.Y. 1980), where the court, in its now famous judgement, disagreed: 'A corporation is not a biological entity for which it can be presumed that any act which extends its existence is beneficial to it', https://www.zoneofinsolvenc yblog.com/wp-content/uploads/sites/128/2015/03/Bloor-v-Dansker.pdf (accessed 8 September 2021).

72 Willett (2005), pp 572, 575.

73 Altman (2018), p 15.
} 
principle of wrongful trading is also recognised, even though it is neither named 'wrongful trading' as in the UK nor stipulated in a concrete provision. The prohibition of wrongful trading in Germany is formed by a mesh of different rules, ${ }^{74}$ which lead to the directors' personal liability for any damages caused to the company and third-party creditors. ${ }^{75}$ Similarly, in Romania, directors have a duty to file for insolvency proceedings if their company is insolvent, but they are also liable for certain actions that are characterised, if committed, as wrongful trading and could lead to liability. Examples include continuing to trade on behalf of the company for their own benefit or using the company's assets for their own benefit. ${ }^{76}$

\subsection{Harmonisation Efforts at the EU Level}

Until recently, EU insolvency law did not provide any guidance for EU Member States concerning the duties of directors in the vicinity of insolvency, nor did any relevant doctrines in this regard. Harmonisation at the EU level in the field of director's liabilities in the vicinity of insolvency is still lacking, and these gaps and deficiencies with regard to substantive rules on directors' duties at the EU level create legal uncertainty and a barrier to cross-border investment. ${ }^{77}$

The first insights on this topic were discussed in 2001, when the High Level Group of Company Law Experts, appointed by the European Commission, recommended that a rule on wrongful trading should be introduced at the EU level. This would hold company directors (including shadow directors) accountable for letting a company continue to do business when it should be foreseen that it would not be able to pay its debts. ${ }^{78}$ In 2003, in its Communication to the Council and the European Parliament, ${ }^{79}$ the Commission supported the recommendations of the High Level Group designed to enhance directors' responsibilities, but indicated that full implementation would require further analysis. The first tangible but small step in the direction of creating a common EU rule can now be seen in Article 19 of the Restructuring Directive. It states that Member States shall ensure that, where there is a likelihood of insolvency, directors have due regard, as a minimum, to the following: (a) the interests of creditors, equity holders, and other stakeholders; (b) the need to take steps to avoid insolvency; and (c) the need to avoid deliberate or grossly negligent conduct that threatens the viability of the business.

\footnotetext{
74 This is formed by Section 64, sentence 1, Limited Liability Company Act, and Section 823, para. 2, Civil Code, in conjunction with Section 15 a, para. 4 , Insolvency act.

75 Lennarts et al. (2017), p 74.

76 McCormack et al. (2016), p 53; Gerner-Beuerle et al. (2013), p A.722. This kind of action would be regarded as a breach of duty in other Member States, and this liability is to be distinguished from wrongful trading as referred to in the UK.

77 European Law Institute (2017), p 167.

78 High Level Group of Company Law Experts (2002), p 12.

79 Communication from the Commission to the Council and the European Parliament - Modernising Company Law and Enhancing Corporate Governance in the European Union - A Plan to Move Forward, COM/2003/0284 final, https://eur-lex.europa.eu/legal-content/EN/ALL/?uri=CELEX:52003DC0284 (accessed 8 September 2021).
} 
Article 19, especially point (c), shows a certain favouritism in recent EU initiatives towards the wrongful trading doctrine. Recital 71 of the Restructuring Directive explains the rationale of the norm in Article 19:

Where the debtor is close to insolvency, it is also important to protect the legitimate interests of creditors from management decisions that may have an impact on the constitution of the debtor's estate, in particular where those decisions could have the effect of further diminishing the value of the estate available for restructuring efforts or for distribution to creditors. It is therefore necessary to ensure that, in such circumstances, directors avoid any deliberate or grossly negligent actions that result in personal gain at the expense of stakeholders, and avoid agreeing to transactions at below market value, or taking actions leading to unfair preference being given to one or more stakeholders. Member States should be able to implement the corresponding provisions of this Directive by ensuring that judicial or administrative authorities, when assessing whether a director is to be held liable for breaches of duty of care, take the rules on duties of directors laid down in this Directive into account.

It is still not clear what impact the Restructuring Directive's norm on directors' duties in the vicinity of insolvency will have on the national insolvency regimes of Member States due to the vague formulation of the norm and the clear avoidance of mentioning the sanctions for not following the proposed minimum standard. This rule mostly aims at encouraging directors to pursue early restructuring when a business is viable ${ }^{80}$ but is not a step towards a harmonised regime regarding the question of a director's liability.

Currently, then, there is no clear-cut and uniform EU-wide guidance, and it is still up to the Member States themselves, in national insolvency regimes, to define the rules for directors' liabilities in the vicinity of insolvency. That the EU does not, or at least not now, intend to move towards greater harmonisation in that regard can also be deduced from the Proposal, where, in the description of the degree of harmonisation, it is, inter alia, stated that '[a] Directive would allow Member States to retain flexibility as to the most appropriate means to implement in their national context principles such as the availability of early warning tools or the duties of directors in the vicinity of insolvency, ${ }^{81}$

\subsection{The Lithuanian Approach and the Impact of the Recent Reform of Insolvency Law}

With the LILE changes ${ }^{82}$ that came into force on 15 July 2021, the Lithuanian legislature tried to implement the Restructuring Directive's provisions. First, it should

\footnotetext{
${ }_{80}$ In the Proposal, this limited aim is clearly recognised: 'Article 18 [Art. 19 in the Restructuring Directive]: contains an obligation for the Member States to impose specific duties on directors in the vicinity of insolvency which would incentivise them to pursue early restructuring when the business is viable.'

81 The Proposal, p 16.

${ }^{82}$ Law No. XIV-450 of 2021 (Register of Legal Acts, 2021, No. 15468).
} 
be noted that the category of 'the likelihood of insolvency' was singled out from the concept of 'financial difficulties' as a separate legal definition and was defined as 'a situation in which the legal person is realistically likely to become insolvent within the next three months'. 83

Second, Lithuania has opted for a relatively straightforward additional implementation approach and has quite literally transposed the provisions of Article 19 of the Restructuring Directive to the LILE. In case of the likelihood of insolvency, ${ }^{84}$ the director is obliged to (1) immediately inform the participants of the legal person about the likelihood of insolvency and offer to resolve the issue of financial difficulties; (2) take actions to protect the interests of the creditors; and (3) avoid deliberate and/or grossly negligent conduct that threatens the viability of the company. ${ }^{85}$

While the first duty of the director in case of the likelihood of insolvency is explicit and definite, the latter two leave plenty of room for interpretation. It is questionable whether the provisions that are speculative in nature are appropriate for a special legal norm. Regarding the second duty, no guidelines can be found as to what actions of the director would legally qualify as protecting the interests of the creditors, while the third obligation raises questions as to its compatibility with the BJR, acknowledged in Lithuanian case law. The SCL has recognised the importance of granting business managers the so-called widened scope of business judgement in order not to suppress directors' reasonable risk-taking that is necessary for business development. ${ }^{86}$ Bold and therefore often risky business initiatives are of high importance in times of a company's financial turbulence. As mentioned above, even according to the existing case law, deliberate and/or grossly negligent conduct of directors deprives them of access to BJR protection. ${ }^{87}$ In other words, the duty to avoid deliberate and/or grossly negligent conduct that threatens the viability of the company already falls within the scope of the director's general duty of care. It can be assumed that the provisions regarding directors' duties in the vicinity of insolvency could lead the national corporate microclimate towards a more conservative and less risk-friendly regime. Simultaneously, it imposes a future task on the national courts to balance up a seemingly stricter director's civil liability statutory approach through case law. On the other hand, it is very likely that the courts, when deciding such cases in the future, will rely on the fact that the relevant obligations are enshrined in law, albeit in the abstract.

It can be noted that the LILE has already provided stipulations on directors' duty to inform shareholders and creditors about the financial difficulties of a company in a timely manner, to propose solutions and amicable agreements to creditors in advance, and to take reasonable steps to avoid insolvency. Together with the rules

\footnotetext{
83 Art. 2(7 $)$ LILE. Accordingly, the definition of 'financial difficulties of a legal person' has been reformulated: '[A] situation where the legal person is insolvent or there is a likelihood of insolvency of the legal person' (earlier, the end of the definition read: '.. or it is realistically likely to become insolvent within the next three months').

84 Also in case of insolvency. See Art. 6(2) LILE.

85 Art. 6(1) LILE.

86 SCL, Case 3K-3-648/2013 (03.12.2013).

87 SCL, Case 3K-7-124/2014 (09.01.2014).
} 
on the liability of directors for not fulfilling these obligations, these stipulations could be considered as adequate fulfilment of the obligations under Article 19 of the Restructuring Directive, and do not necessarily require additional improvements.

Scholars widely agree that determining when a director's obligations arise due to insolvency is, with respect to the creditors, a matter of critical significance. ${ }^{88}$ Keay argues that pinpointing the shift when a director begins to be subject to the obligation to take into account the interests of the creditors is considered as one of the biggest issues in the common law approach. ${ }^{89}$ This debate is weighty in the context of an analysis of a director's civil liability in the stages of pre-insolvency and insolvency. Without a clear reference point, it will be difficult for a director to predict with confidence the point in time in the period before insolvency proceedings commenced to which a court will refer in considering an action for breach of the director's obligations. ${ }^{90}$ The new definition of the likelihood of insolvency in the LILE provides this reference point, although its clarity remains questionable. The recent amendments to the LILE formally declare that the so-called 'grand shift' happens in the vicinity of a firm's insolvency instead of at the point of its factual insolvency. This extends the period when creditors and insolvency practitioners are entitled to ex post examine the director's conduct and raise questions as to their civil liability.

The novel explicit director's duties in case of the likelihood of insolvency provide legal tools to pressure directors to constantly monitor the company's financial situation, to take appropriate measures on time, and thus engage in early restructuring and avoid business liquidation. Another novelty-the Early Warning System (EWS)_introduced in Lithuania while implementing the Restructuring Directive should remind the directors of Lithuanian SMEs of their duties in the vicinity of insolvency. ${ }^{91}$ The logic behind the new Lithuanian approach is following the corporate rescue culture paradigm promoted by the EU. However, the novel Lithuanian statutory regulation of the director's duty in the vicinity of insolvency has made the national director's civil liability regime stricter, adding uncertainty to the existing regulation.

Generally, Lithuania follows a hybrid approach regarding a director's duties in the vicinity of insolvency. In Lithuanian case law and doctrine, the general obligation to initiate insolvency proceedings in a timely manner is regarded as an imperative duty of the director, and failure to comply with this duty is unlawful inaction that may cause damage and therefore incur a director's civil liability. ${ }^{92}$ This is a clear element of the liability for delaying insolvency proceedings doctrine.

\footnotetext{
${ }^{88}$ E.g. Wabl (2019), p 49; Hudson (2014), pp 84-86.

89 Keay (2015), p 151.

90 UNCITRAL (2013), p 14.

91 EWS started operating in Lithuania on 17.07.2021. The Lithuanian State Tax Inspectorate will regularly assess the financial situation of legal entities and after identifying the potential risk of insolvency will notify them personally. Such entities can receive consultations from the Lithuanian export development agency Enterprise Lithuania regarding restoration of its solvency.

92 E.g., SCL, Case 3K-3-453/2014 (27.10.2014); Case 3K-3-228/2011 (05.05.2011); Kavalnè and Norkus (2011), p 18.
} 
The above-mentioned changes in the LILE regarding the director's duties in the vicinity of insolvency were formulated under the apparent influence of another legal approach - the wrongful trading doctrine. The preeminent attributes of the doctrine are also observed in the Lithuanian judicial interpretation regarding a director's duty to commence insolvency proceedings in a timely manner. The SCL explicated that although a company that has already become insolvent may not be forced into insolvency repeatedly, the situation of the insolvent company may be deliberately or negligently worsened. ${ }^{93}$ The courts also ascertained causation between a director's mismanagement and the subsequent worsening of the situation of the insolvent company and stated, e.g., in Case e2-1616-798/2019, that the 'director infringed on creditors' interests by continuing the activity of the insolvent company'. As a result, the value of the company's assets decreased to such an extent that its overdue liabilities exceeded the total value of the company's assets, and the creditors entirely lost the opportunity to satisfy their claims. ${ }^{94}$

It needs to be mentioned that the duty to act on time does not mean that the company should be set on the path to liquidation. In Lithuania, when insolvency proceedings are initiated, there are a few options available: amicable agreement with creditors; restructuring as a priority way of dealing with financial difficulties when the company is still viable (which means that the company may continue to operate and rehabilitate itself); and bankruptcy (liquidation) as the ultima ratio. This kind of approach is chosen based on the international recommendations to encourage debtor companies to file for insolvency before their circumstances become too dire, ${ }^{95}$ and also as response to the requirements of the Restructuring Directive regarding the duties of the directors where there is a likelihood of insolvency. The practice in Lithuania shows that even strict regulation of the duty to file does not actually solve the problem of late filing. Therefore, after the insolvency reform in Lithuania the focus fell on the early duty of the director of the debtor to report a failing business's situation to shareholders and creditors in a timely manner, and to propose various solutions on how to save the business's viability. ${ }^{96}$ According to Article 8, the initiation of the insolvency process is equated to a formal attempt to reach an agreement with the company's creditors on aid to overcome its financial difficulties. It could be argued that such an agreement is similar to the tool of 'schemes of arrangement' known in English law (Part 26 of the Companies Act 2006), which is also recognised in the European Model Company Act $^{97}$ (Part 2 of Chapter 13), and is used as a flexible mechanism for the restructuring of the capital in the company. ${ }^{98}$ Thus, it can be inferred that the regulation discussed imposes the duty to start a formal dialogue with creditors regarding aid to the company, and only in the case of failure

\footnotetext{
93 SCL, Case 3K-3-597/2013 (22.11.2013).

94 Court of Appeal of Lithuania, Case e2-1616-798/2019 (20.11.2019).

95 World Bank (2014), p 96.

96 See Art. 6 LILE.

97 Andersen et al. (2017).

98 See also Patakyova and Gramblickova (2016), pp 346-350.
} 
to reach an agreement must the director initiate judicial insolvency proceedingseither restructuring or bankruptcy.

Hence, the new LILE first urges directors to initiate a search for the means to restore solvency, together with the participants of the company, second, to start a formal dialogue with creditors in seeking to receive aid to overcome financial turbulence, third, if the first two steps do not achieve the desired result, to commence a formal procedure for the restructuring of the company, and fourth, if none of these are successful, to file for bankruptcy. The law also stipulates generally and somewhat vaguely that the director shall be liable for the damage caused by non-fulfilment of the duties prescribed by the LILE (Article 13(1)). This provides room for more versatile and dynamic conduct on the part of the director in the face of the company's financial difficulties. At the same time, the new legal approach should alleviate directors' concerns regarding potential civil liability for resorting to different means to revive a business instead of immediately filing for bankruptcy. The apparent aspiration of the Lithuanian lawmakers - to promote early restructuring and ensure preservation of viable businesses-brings both new opportunities and novel challenges. One of the main questions regarding the duty to file for insolvency proceedings concerns the definition of the circumstances triggering this duty. The specific point at which the director must file for insolvency is not always clear. In some Member States (e.g., Austria, Germany and Poland), the relevant triggering factors are illiquidity (when the company is unable to pay its debts as they become due, or 'cash-flow insolvency') and over-indebtedness (when the company's liabilities, including its contingent and prospective liabilities, exceed its assets, or 'balance-sheet insolvency'), while other Member States (e.g., Belgium, France and Latvia) only make use of the 'cessation of payments of debts' requirement. ${ }^{99}$

Under the new Lithuanian legislation, a company's insolvency is the state wherein it is unable to fulfil its financial obligations in due time or its liabilities exceed the value of its assets. ${ }^{100}$ Thus, a combination of alternative tests, i.e., the 'equitable definition test' and the 'balance sheet test', is invoked in the LILE to generate a new definition of insolvency. In the international doctrine, it is argued that if corporate insolvency is defined as having more liabilities than assets on hand, or as the inability to pay a debt as it becomes due, reasonable individuals may reach different conclusions as to when exactly insolvency has taken place, because these definitions may be hard to apply to a specific fact pattern. ${ }^{101}$ The position of the Lithuanian lawmaker received criticism in the press from Lithuanian advocates and insolvency practitioners. The main arguments were that there is no statutory reference to the scope of overdue financial obligations in relation to the entirety of a company (as compared with German regulation), and also that there is no indication of the overdue period, which may be significant in assessing the real scope of a company's financial problems in a particular case. The new approach of the balance sheet test application to indicate insolvency has also raised debates. Practitioners

\footnotetext{
99 European Law Institute (2017), p 166.

100 Art. 2(7) LILE.

101 Barondes (1998), p 71; Hudson (2014), p 85.
} 
shed light on a possible paradox, noting that if a company, for example, receives a loan above the value of its assets, even in the case of timely repayment of this loan it may be formally considered insolvent. ${ }^{102}$

One can argue that the new Lithuanian definition of insolvency is somewhat lax, leaving plenty of room for redundant interpretations. Such a loose definition of insolvency may appear to extend the potential liability of the director in case of failure to file for insolvency in a timely manner.

In Lithuania, the importance of the definition of this 'trigger' insolvency moment is illustrated by the SCL's widely acknowledged practice of stating that the indication of the exact moment when a director's duty to file for insolvency arises is straightforwardly related to the amount of damage to be compensated. ${ }^{103}$ The SCL has emphasised that civil liability is not a particular sanction for a director's unlawful conduct, and the amount of damage has to be assessed on a case-by-case basis following the moment when a director's duty emerged. Thus, in some cases, the damage may be equal to the amount of all of the creditors' claims or a proportion of unsatisfied claims, whereas in other cases the recognised damage might be respectively smaller where it is determined that only part of the debt was formed due to the director's failure to file for bankruptcy in a timely manner. ${ }^{104}$ Especially in insolvency cases where not enough company assets are left to cover the bankruptcy administration costs, insolvency practitioners widely use the argument of failing to file for insolvency on time to reach an agreement with the former director to summon the agreed upon sum even prior to litigation. This presumably leads to some anxiety on the part of directors regarding the assessment of the exact moment of insolvency (and in addition, following the latest amendments in the LILE, the exact moment of the likelihood of insolvency), and any related personal liability. However, keeping in mind that under the new Law directors are obliged to take a range of actions instead of immediately filing for bankruptcy, the recent, more open, definition of insolvency is seen as a tool to urge directors to initiate a resolution of financial difficulties at the earliest possible stage.

Therefore, in the most recent Lithuanian jurisprudence a shift in interpretation has been observed, seeking to better conform to the reality of modern business and create premises for mitigating the civil liability regime governing directors. For example, the SCL explicated that the question of the solvency of a company should not be limited to the assessment of the formal relationship between overdue liabilities and the value of the assets on the balance sheet. The factual circumstances related to the nature of the activities of the company (inter alia, in the context of financial fluctuations and trends in the market) have to be evaluated alongside: retrospectives (past performance and changes), results (whether the company's activity has been generating a loss or gain recently); and perspectives (the company's prospects of restoring normal activities in the short term and thus stabilising the financial situation). ${ }^{105}$

\footnotetext{
102 Karpickis (2020).

103 SCL, Case 3K-3-344/2014 (27.06.2014).

104 SCL, Case 3K-3-453/2014 (27.10.2014).

105 SCL, Case e3K-3-105-684/2019 (20.05.2019).
} 
Additionally, in directors' civil liability cases that seek to redress damage resulting from untimely actions in the stages of insolvency and imminent insolvency, the focus is shifting towards the actual moment that the director starts to become apprehensive about the company's financial situation. The point when a prudent and responsible incumbent of the office knew, or ought to have known, that the company was insolvent, or that insolvency was imminent, is considered as an essential criterion and the main reference point. The knowledge of the director is being examined at a point before the commencement of insolvency proceedings, when they knew, or ought to have known, that the company was insolvent, or that insolvency was inevitable, and there was no reasonable prospect that the company could avoid having to commence insolvency proceedings. The rationale of this approach is to catch directors who are unreasonable in their running of a company that is experiencing financial difficulty, and to provide incentives to take appropriate action at an optimal time. ${ }^{106}$ It is required that the director's judgement be examined against the knowledge that a reasonably competent officer should or ought to have had in similar circumstances.

Seeking to insure themselves against incurring civil liability in the future, directors should implement the so-called 'going concern principle' at the earliest possible stage of financial difficulties arising. The principle involves constant assessment of the company's financial status, inspection and supervision thereof in order to detect any symptoms of an upcoming crisis in a timely manner, and enforcement of efficient preventive measures to rectify such a situation. ${ }^{107}$ As if to express support for a director's pro-active role in the vicinity of insolvency, lawmakers introduced a new definition of 'the viability of a legal person' as a status where the company carries out an economic commercial activity that will enable it to fulfil its obligations in the future. ${ }^{108}$ However, according to the SCL's practice, the fact alone that the company is pursuing its regular commercial activities is not sufficient to eliminate the director's liability for failure to file for bankruptcy in a timely manner. ${ }^{109}$

In summary, the recent regulatory changes in Lithuanian insolvency law have introduced the separate legal definition of the likelihood of insolvency for the first time and have defined novel directors' duties during that phase. The tightened directors' civil liability regime due to the entrenched special directors' duties in the vicinity of insolvency is considered a legal tool to fulfil the apparent aspirations of the Lithuanian lawmakers, i.e., to promote early restructuring and ensure preservation of viable businesses. The new LILE also imposed an extended duty for directors to take a range of actions in case of a company's insolvency: initiating a dialogue with shareholders and creditors to overcome financial difficulties; proposing solutions for saving the viable business and filing for restructuring; and only filing for bankruptcy as an ultima ratio. The new Lithuanian legal approach, implementing the provisions

\footnotetext{
106 UNCITRAL (2013), p 15.

107 Bitè and Jakuntavičiūtė (2014a), p 118.

108 Art. 2(6) LILE.

109 SCL, Case 3K-3-344/2014 (27.06.2014).
} 
of the Restructuring Directive and promoting the corporate rescue culture paradigm, brings both new opportunities and novel challenges.

\section{Temporary Changes Due to the COVID-19 Outbreak}

In this Section, we will first determine the main challenges posed by the COVID-19 outbreak in relation to the problems of corporate solvency, and then focus on the Lithuanian response to this challenge and its impact on the liability of directors in the vicinity of insolvency.

In a systemic crisis such as the COVID-19 pandemic, the scramble for liquidity increases the risk of pushing viable firms into liquidation, especially vulnerable micro, small and medium enterprises. ${ }^{110}$ The World Bank singled out three phases in this crisis which might be considered sequential, or which might have significant overlap depending upon the context of the respective country. In Phase 1, creditors, faced with the challenges of their own liquidity, will prematurely push viable firms into insolvency, resulting in significant value destruction. In Phase 2, the insolvency system will have to respond to an increase both in failing firms and in firms that cannot restructure their debts without an out-of-court workout or formal restructuring procedures. Phase 3 will require a focus largely on individuals dealing with the aftermath of personal financial distress resulting from the crisis. ${ }^{111}$

Many countries have enacted insolvency-related measures aimed at allowing firms and consumers to have some breathing space until the markets have stabilised. ${ }^{112}$ These responses are a mix of regulatory forbearance, higher barriers to entry into formal insolvency proceedings, and the extension of procedural deadlines.

One of the main measures introduced in response to the challenges faced during Phase 1 -aimed at preventing viable firms from being prematurely pushed into insolvency — was the suspension, for a limited period of time, of the director's duty to put companies into insolvency, along with the associated personal liability. ${ }^{113}$ This measure was relevant for most countries that follow the 'duty to file approach' at least partially, including Lithuania with its hybrid approach. Suspending the duty to file based on over-indebtedness — and the corresponding liability - in the current crisis regime was advised in order to prevent a flood of insolvencies. ${ }^{114}$ Similarly, in some countries, directors who continue to carry on business trading while the enterprise is insolvent are personally liable for wrongful trading, and potentially fraudulent trading. Suspending the personal liability of directors for wrongful trading has offered some relief during this crisis, when assessing business solvency has been difficult.

\footnotetext{
${ }^{110}$ Menezes and Muro (2020), p 1.

111 Ibid., p 2.

112 See, e.g., DLA Piper (2020).

113 Menezes and Muro (2020), p 3.

114 CERIL (2020), p 2.
} 
Following the international recommendations and examples from other EU Member States (such as Germany, where a new law suspending the mandatory obligations to file for insolvency proceedings and mitigating liability risks for managing directors and creditors was quickly enacted ${ }^{115}$ ), Lithuania adopted the Law on the Impact of the Consequences of the New Coronavirus (COVID-19) on the Application of the LILE ${ }^{116}$ (hereinafter COVID-19 Law), which entered into force on 25 April 2020 for the duration of the quarantine regime period. An extension regarding the relaxation of obligations to file for insolvency and concerning the protection of ongoing restructuring proceedings could have been enacted by government decree until 31 December 2020, ${ }^{117}$ but was not adopted. In November 2020, the second quarantine regime was announced, but the protection afforded by the COVID-19 Law was not extended.

The COVID-19 Law provided for the suspension of a director's duty to initiate insolvency if the company was in the situation of insolvency. However, other obligations continued to apply, i.e., the duty to inform the shareholders and creditors about the difficult financial situation and propose to the creditors to conclude an agreement of financial aid to save an otherwise viable business. Contrary to international recommendations that this suspension of duty to file should not depend on further substantial requirements, like, for instance, the need for state aid or proof of being affected by the current crisis (as in the German response), ${ }^{118}$ Lithuania included such restrictions. The COVID-19 Law stated that the suspension was applicable only if the company faced distress after the day of the announcement of the first quarantine in Lithuania (16 March 2020) - in other words, if the company was in difficulties because of the coronavirus pandemic. The question of onus probandi and the difficulty of proving this fact immediately arise for the creditors. Additionally, there is no guarantee that the court will share the same view when evaluating whether the company's difficulties were caused by the pandemic or other factors, and so there is no legal certainty for the director that there will be no liability case against their decision not to pursue the path of formal insolvency proceedings. In Lithuania, as opposed to recent amendments to the German insolvency regime, there is also no legal presumption that a company that faced distress at the time of the announcement of the quarantine was in difficulties because of the coronavirus pandemic. Therefore, directors need to have proof that allows them to convince the court that the exemption to the duty to file is applicable in their case.

\footnotetext{
115 According to the German Act to Mitigate the Consequences of the COVID-19 Pandemic in Civil, Insolvency and Criminal Procedural Law, the obligation to file for insolvency proceedings is suspended on a temporary basis for companies facing an insolvency due to the COVID-19 pandemic. The new law was enacted on 27 March 2020, with the regulations regarding insolvencies having retroactive effect as of 1 March 2020. The suspension does not apply if: the insolvency was not caused by the consequences of the COVID-19 pandemic, or there is no prospect of resolving the insolvency.

116 No. XIII-2861 of 2020 (Register of Legal Acts, 2020, No. 8725).

117 It was inspired by the CERIL Executive Statement (2020-1), CERIL (2020), and comparative examples in other countries.

118 CERIL (2020), p 3.
} 
The COVID-19 Law also included restrictions on creditors filing for insolvency, protection of ongoing restructuring proceedings (e.g., failure to pay taxes due would not trigger the usual termination of restructuring proceedings during the extended quarantine period), and safe harbour rules for transactions using state financial support measures offered due to the coronavirus. Such transactions could not be challenged if the company subsequently went bankrupt. The main shortcoming of such an approach was the very narrow application area of this norm: it did not protect transactions in general from voidance claims of the insolvency administrators if the company went bankrupt in the future.

Due to the extraordinary character of the new Law, the courts also faced challenges when applying its norms. For example, some first instance courts interpreted the norms of the COVID-19 Law not only as suspending a director's duty to file, but also as suspending their right to file for insolvency during the quarantine regime. ${ }^{119}$ Of course, it was not the intention of the Lithuanian Parliament to prevent the use of the protection offered by the insolvency regime to the debtors and creditors in circumstances where the director, after carefully considering the situation, sees no other way than to proceed with formal insolvency proceedings. Such a suspension of the duty to file as introduced in the COVID-19 Law clearly aimed only at the relief of the directors from any connected liability, but should not impact their right to choose the path most suitable for their company and its creditors.

\section{Conclusions}

The new Lithuanian Law on Insolvency of Legal Entities (LILE) modifies the entire perception of insolvency, which no longer implies the inevitable end of the legal person, since the LILE offers the formal possibility to shift from bankruptcy to a restructuring procedure and to thereby possibly regain the company's full financial stability.

The obligation of a director to commence insolvency proceedings in a timely manner when a company faces distress is regarded as the fundamental duty owed to its creditors. Recent Lithuanian legal regulation imposes an extended director's duty to take a range of actions in case of a company's insolvency, including: initiating a dialogue with shareholders and creditors in order to overcome financial difficulties and take steps to save a viable business; filing for restructuring as the first measure if no agreement is reached with the creditors on financial help; and only filing for bankruptcy as an ultima ratio.

Despite the visible contradictions and ambiguities, a new, rather open definition of insolvency, the novel institution of a mandatory dialogue with creditors and shareholders and diverging concepts of financial difficulties and business viability introduced by the new Law form solid grounds for a more favourable corporate rescue environment.

$\overline{119}$ Vilnius Regional Court, Case Nr. eB2-3228-910/2020 (12.05.2020). 
The LILE already provided for provisions on the directors' duty to react to the financial difficulties of a company in a timely manner and on their subsequent liability. These stipulations could be considered as adequately fulfilling the obligations under Article 19 of the Restructuring Directive and did not necessarily require additional improvements. Nevertheless, Lithuania has opted for a relatively straightforward additional implementation approach and has directly transposed the provisions of Article 19 to the LILE. Thus, the additional, however rather vague and speculative, director's duties during this phase were established.

The novel statutory directors' duties in case of the likelihood of insolvency can serve as legal tools to encourage managers to diligently monitor the company's financial situation so as to take timely measures and thus engage in early restructuring and avoid business liquidation. The logic behind the new Lithuanian approach is following the corporate rescue culture paradigm promoted by the EU. However, the novel Lithuanian statutory regulation of the director's duties in the vicinity of insolvency has made the national director's civil liability regime stricter and has brought an additional degree of uncertainty to the existing regulation. Simultaneously, it has imposed a future task on the national courts to balance up a seemingly stricter director's civil liability statutory approach through case law.

\section{References}

Abramavičius A, Mikelènas V (1999) Imonių vadovų teisinè atsakomybė [Legal liability of company managers]. Teisinès informacijos centras, Vilnius

Altman EI (2018) Applications of distress prediction models: what have we learned after 50 years from the Z-score models? Int J Financ Stud 6(70):1-15. https://www.mdpi.com/2227-7072/6/3/70/pdf. Accessed 8 Sept 2021

Andersen PK et al. (2017) European Model Company Act (EMCA), 1st edn. Nordic \& European Company Law Working Paper No. 16-26. https://ssrn.com/abstract=2929348. Accessed 8 Sept 2021

Armour J, Hertig G, Kanda H (2017) Transactions with creditors. In: Kraakman RH et al. (eds) The anatomy of corporate law: a comparative and functional approach, 3rd edn. Oxford University Press, Oxford, pp 109-143

Barondes RR (1998) Fiduciary duties of officers and directors of distressed corporations. Geo Mason L Rev 7(1):45-104. https://scholarship.law.missouri.edu/facpubs/29/. Accessed 8 Sept 2021

Barton NE et al. (1998) The business judgement rule: fiduciary duties of corporate directors. Aspen Publishers, Alphen aan den Rijn

Bitè V, Gumuliauskienè G (2016) The business judgment rule in Lithuania. Eur Bus Org Law Rev 17(4):555-576

Bitè V, Jakuntavičiūte G (2014a) Is the limited liability doctrine applicable to company directors? Eur Scient J 10(16):109-128. https://eujournal.org/index.php/esj/article/view/3515. Accessed 8 Sept 2021

Bitė V, Jakuntavičiūtè G (2014b) Types of companies' management bodies under Lithuanian law. Eur Sci J 10(16):43-64. https://core.ac.uk/download/pdf/236408991.pdf. Accessed 8 Sept 2021

Brinkmann M (2019) Chapter I. General provisions. Articles 1-4. In: Brinkmann M (eds) European Insolvency Regulation. Commentary. C.H. Beck, Baden-Baden, pp 25-69

CERIL (2020) CERIL Executive Statement 2020-1 on COVID-19 and insolvency legislation, 20 March 2020. https://www.ceril.eu/news/ceril-statement-2020-1. Accessed 3 Oct 2020

Davies P et al. (1997) Gower's principles of modern company law, 6th edn. Sweet \& Maxwell, London 
de Weijs RJ (2018) Harmonization of European insolvency law: preventing insolvency law from turning against creditors by upholding the debt-equity divide. ECFR 15(2):403-444. https://doi.org/10. 1515/ecfr-2018-0007. Accessed 8 Sept 2021

DLA Piper (2020) An international guide to changes in insolvency law in response to COVID-19. https:// www.dlapiper.com/en/us/insights/publications/2020/03/coronavirus-what-european-governmentsare-doing-to-support-businesses/. Accessed 3 Oct 2020

European Law Institute (2017) Rescue of business in insolvency law. https://www.europeanlawinstitute. eu/fileadmin/user_upload/p_eli/Publications/Instrument_INSOLVENCY.pdf. Accessed 3 Oct 2020

Flannigan R (2006) The strict character of fiduciary liability. New Zealand L Rev 2:209-242. https:// papers.ssrn.com/sol3/papers.cfm?abstract_id=940659. Accessed 8 Sept 2021

Gerner-Beuerle C et al. (2013) Annex to study on directors' duty and liability. LSE Enterprise Limited, London. http://ec.europa.eu/internal_market/company/docs/board/2013-study-reports_en.pdf. Accessed 8 Sept 2021

Gevurtz FA (2000) Corporation law. West Group, St. Paul Minn

Greičius R (2007) Privataus juridinio asmens vadovo fiduciarinès pareigos [Fiduciary duties of a private legal entity]. Teisinès informacijos centras, Vilnius

Gurrea-Martínez A (2018) Re-examining the law and economics of the business judgment rule: notes for its implementation in non-US jurisdictions. J Corp Law Stud 18(2):417-438. https://doi.org/10. 1080/14735970.2017.1412688. Accessed 8 Sept 2021

Havel B (2018) Shareholders' agreement arrangement in pre-insolvency and insolvency law. In: Mock S, Csach K, Havel B (eds) International handbook on shareholders' agreements: regulation, practice and comparative analysis. De Gruyter, Berlin/Boston, pp 99-118

High Level Group of Company Law Experts (2002) Report of the High Level Group of Company Law Experts on a Modern Regulatory Framework for Company Law in Europe, 4 November 2002, Brussels. https://www.docsity.com/en/report-of-the-high-level-group-of-company-law-experts-on-amodern-regulatory-framework-for-company-law-in-europe/435687/. Accessed 3 Oct 2020

Hill JG (2020) Shifting contours of directors' fiduciary duties and norms in comparative corporate governance. UCI J Int Transnatl Comp Law 5:8. https://scholarship.law.uci.edu/ucijil/vol5/iss1/8. Accessed 8 Sept 2021

Hudson WH (2014) The fiduciary duties of directors and officers in insolvent corporations: a uniform international standard? Lincoln L Rev 40-41:56-96

Jarusevičius J (2019) Ar pagrịstai verslo sprendimo taisyklè priskiriama prezumpcijos kategorijai? [Is there any basis for categorizing the business judgment rule as a presumption?]. Teisè 112:186-202. https://doi.org/10.15388/Teise.2019.112.10. Accessed 8 Sept 2021

Kandestin CD (2007) The duty to creditors in near-insolvency firms: eliminating the "near-insolvency" distinction. Vanderbilt L Rev 60(4):1235-1272. https://scholarship.law.vanderbilt.edu/vlr/vol60/ iss4. Accessed 8 Sept 2021

Karpickis K (2020) Naujajame nemokumo įstatyme ižzvelgiamos grèsmès [Threats observed in the new insolvency law]. Delfi, 15 January 2020. https://www.delfi.lt/verslas/nuomones/kazimieras-karpi ckis-naujajame-nemokumo-istatyme-izvelgiamos-gresmes.d?id=83272335. Accessed 3 Oct 2020

Kavalnè S, Norkus R (2011) Bankroto teisè. Antroji knyga [Bankruptcy law. Second book]. Justitia, Vilnius

Keay K (2005) Wrongful trading and the liability of company directors: a theoretical perspective. Legal Stud 25(3):431-461. https://doi.org/10.1111/j.1748-121X.2005.tb00678.x. Accessed 8 Sept 2021

Keay A (2015) The shifting of directors' duties in the vicinity of insolvency. Int Insolvency Rev 24(2):140-164. https://doi.org/10.1002/iir.1236. Accessed 8 Sept 2021

Lennarts L et al. (2017) Directors' liability in the twilight zone, Reports 2017. Eleven International Publishing, The Hague. http://www.naciil.org/uploads/files/preadviezen-nvrii-directors-liability-in-thetwilight-zone.pdf. Accessed 8 Sept 2021

Madaus S (2019) Chapter I. General provisions. Article 6. In: Brinkmann M (eds) European Insolvency Regulation. Commentary. C.H. Beck, Baden-Baden, pp 74-82

McCormack G et al. (2016) Study on a new approach to business failure and insolvency. Comparative legal analysis of the Member States' relevant provisions and practices. European Union, January 2016. https://ec.europa.eu/info/sites/info/files/insolvency_study_2016_final_en.pdf. Accessed 5 Oct 2020

Menezes A, Muro S (2020) COVID-19 outbreak: implications on corporate and individual insolvency. World Bank, Finance Series. http://pubdocs.worldbank.org/en/912121588018942884/COVID-19Outbreak-Implications-on-Corporate-and-Individual-Insolvency.pdf. Accessed 3 Oct 2020 
Mevorach I, Walters A (2020) The characterization of pre-insolvency proceedings in private international law. Eur Bus Org Law Rev 21:855-894. https://doi.org/10.1007/s40804-020-00176-x. Accessed 8 Sept 2021

Mikelènas V et al. (2002) Lietuvos Respublikos civilinio kodekso komentaras. Antroji knyga. Asmenys [Commentary on the Civil Code of the Republic of Lithuania. Second Book. Persons]. Justitia, Vilnius

Millner RB et al. (2007) Potential liability for deepening insolvency and breach of fiduciary duty to creditors. In: ABA Section of Litigation Annual Conference, 11-14 April 2007. https://www.iiiglobal. org/sites/default/files/robertmillner.pdf. Accessed 3 Oct 2020.

Patakyova M, Gramblickova B (2016) Bankruptcy and liquidation: current legal situation in European and international context, solutions under the European Model Company Act (EMCA). ECFR 13(2):322-350

Scarlino D (2018) Zone of insolvency, directors' duties and creditors' protection in US. Eur Bus Law Rev 29(1):1-31

Taylor L (2018) Directors' duties on insolvency in New Zealand: an empirical study. N Zeal Univ L Rev 28(2):171-195

UNCITRAL (2013) UNCITRAL legislative guide on insolvency law. Part four: directors' obligations in the period approaching insolvency. United Nations, Vienna. https://www.uncitral.org/pdf/english/ texts/insolven/Leg-Guide-Insol-Part4-ebook-E.pdf. Accessed 8 Sept 2021

Wabl G (2019) To file, or not to file: that is the question. Directors' duties in the company crisis. Bus L $\operatorname{Rev} 40(2): 49-65$

Waxman D (2014) Playing with house money: director's fiduciary duties in a distressed corporation. West for L Rev 49(4):1193-1212

Willett S (2005) The shallows of deepening insolvency. Bus Lawyer 60(2):549-575. http://www.jstor.org/ stable/40688279. Accessed 8 Sept 2021

Williams R (2015) What can we expect to gain from reforming the insolvent trading remedy? MLR 78(1):55-84. https://doi.org/10.1111/1468-2230.12106. Accessed 8 Sept 2021

World Bank (2014) Resolving insolvency, doing business 2015. https://www.doingbusiness.org/en/repor ts/global-reports/doing-business-2015. Accessed 9 Jan 2022

Publisher's Note Springer Nature remains neutral with regard to jurisdictional claims in published maps and institutional affiliations.

\section{Authors and Affiliations}

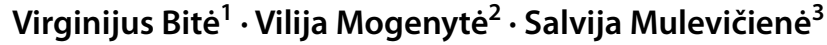

Vilija Mogenytė

vimogenyte@stud.mruni.eu

Salvija Mulevičienè

kavalne@mruni.eu

1 Professor (Law), Institute of Private Law, School of Law, Mykolas Romeris University, Vilnius, Lithuania

2 Lecturer, Institute of Private Law, School of Law, Mykolas Romeris University, Vilnius, Lithuania

3 Associate Professor (Law), Institute of Private Law, School of Law, Mykolas Romeris University, Vilnius, Lithuania 